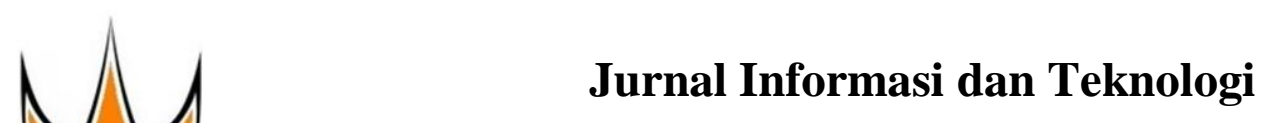

http://www.jidt.org

2021 Vol. $3 \quad$ No. $4 \quad$ Hal: $227-232$

e-ISSN: 2714-9730

\title{
Sistem Pakar Dalam Menganalisa Penyakit Perut Dengan Menggunakan Metode Certainty Factor
}

\author{
Annisa Amalia ${ }^{1 凶}$, Gunadi Dwi Nurcahyo ${ }^{2}$, Yuhandri Yunus ${ }^{3}$ \\ ${ }^{1}$ Independent Researcher \\ ${ }^{2}$ Universitas Putra Indonesia YPTK Padang \\ safirazo11a. anez@gmai 1.com
}

\begin{abstract}
Food technology that is increasingly advanced makes people tend to consume fast food, as well as foods that contain chemicals. This causes the tendency of an unhealthy lifestyle and becomes one of the factors that cause stomach disease. Stomach disease can be experienced at the age of children to adulthood. Unhealthy lifestyle means eating patterns that are initially consumptive on healthy foods and then turn into consumptive foods that are less healthy. Not only food, rarely exercise is also likely to cause pain in the stomach. Diagnosing stomach disease is still carried out by conducting face-to-face consultations with health workers, which can take a long time and cost a lot of money. Lack of information on stomach disease sufferers about the symptoms of stomach disease, causes patients not to know the type of stomach disease they are experiencing. This is the goal of research that will build an expert system software that is expected to be able to analyze stomach diseases and help the community, stomach sufferers and health workers in diagnosing types of stomach diseases. The method used in this study is Certainty Factor (CF) or the certainty value of a disease. Expert system software development is done by analyzing software requirements, system user needs. The dataset of this study is the symptoms and types of stomach diseases that occur at the Salido Health Center. The result of the system built is the result of the diagnosis of stomach disease with the percentage of certainty value from the calculation using Certainty Factor. The system will also provide information about the description, causes and prevention of the types of stomach diseases diagnosed. With the construction of an expert system of stomach diseases, it is hoped that this research can be a reference for users in diagnosing stomach diseases. The accuracy results obtained after testing the system is $80 \%$.
\end{abstract}

Keywords: Expert System, Analysis, Lifestyle, Stomach Disease, Certainty Factor.

\begin{abstract}
Abstrak
Teknologi pangan yang semakin maju membuat masyarakat cenderung mengkonsumsi makanan cepat saji, maupun makanan yang mengandung zat kimia. Hal ini menyebabkan kecenderungan dari pola hidup yang tidak sehat dan menjadi salah satu faktor yang menyebabkan penyakit perut. Penyakit perut dapat dialami pada usia anak-anak hingga usia dewasa. Pola hidup tidak sehat maksudnya ialah pola makan yang awalnya konsumtif terhadap makanan sehat kemudian berubah menjadi konsumtif pada makanan yang kurang sehat. Bukan hanya makanan, jarang berolahraga juga berkemungkinan menimbulkan rasa sakit pada perut. Diagnosa penyakit perut, sampai saat ini masih dilakukan dengan melakukan konsultasi tatap muka dengan petugas kesehatan yang dapat memakan waktu lama serta biaya yang banyak. Kurangnya informasi penderita penyakit perut terhadap gejala penyakit perut, menyebabkan pasien tidak mengetahui jenis penyakit perut yang sedang dialaminya. Hal ini yang menjadi tujuan penelitian yang akan membangun sebuah perangkat lunak sistem pakar yang diharapkan dapat menganalisis penyakit perut dan membantu masyarakat, penderita penyakit perut maupun petugas kesehatan dalam mendiagnosis jenis penyakit perut. Metode yang digunakan dalam penelitian ini ialah metode Certainty Factor (CF) atau nilai kepastian suatu penyakit. Pembangunan perangkat lunak sistem pakar dilakukan dengan menganalisis kebutuhan perangkat lunak, kebutuhan pengguna sistem. Dataset penelitian adalah gejala dan jenis penyakit perut yang terjadi di Puskesmas Salido. Hasil dari sistem yang dibangun adalah hasil diagnosa penyakit perut dengan persentase nilai kepastian dari perhitungan yang menggunakan metode Certainty Factor. Sistem juga akan memberikan informasi tentang keterangan, penyebab dan pencegahan jenis penyakit perut yang didiagnosa. Dengan dibangunnya sistem pakar penyakit perut, diharapkan penelitian ini dapat menjadi acuan pengguna dalam mendiagnosa penyakit perut. Hasil akurasi yang diperoleh setelah melakukan pengujian sistem pakar penyakit perut dengan metode CF adalah terdapat $80 \%$
\end{abstract}

Kata kunci: Sistem Pakar, Analisis, Pola Hidup, Penyakit Perut, Certainty Factor.

(C) 2021 JIdT

\section{Pendahuluan}

Teknologi pangan yang semakin maju menjadi salah satu penyebab masyarakat cenderung mengkonsumsi makanan cepat saji, maupun makanan yang mengandung zat kimia atau adiktif. Kecenderungan dalam mengkonsumsi makanan seperti itu lah yang menjadi faktor dari pola hidup yang tidak sehat yang sering menyebabkan penyakit perut pada masyarakat, baik dikalangan orang dewasa maupun kalangan anak anak. Perut merupakan salah satu bagian dari tubuh manusia yang memiliki otot dan rongga yang dapat berubah ukuran dan didalam perut terdapat organ organ yang berfungsi sebagai organ pencernaan yang penting, seperti lambung dan usus. Sehingga penyakit perut adalah rasa sakit yang dirasakan oleh manusia

Diterima: 27-08-2021 | Revisi: 01-10-2021 | Diterbitkan: 31-12-20121| doi: 10.37034/jidt.v3i4.159 
pada bagian perut yang bisa saja berasal dari salah satu organ pencernaan tadi.

Penyakit perut dapat disebabkan oleh pola mengkonsumsi makanan dan minuman telah terkontaminasi kuman dan bakteri dan masuk kedalam tubuh manusia melalui saluran pencernaan. Beberapa penyakit perut yang umum dialami pasien adalah mencret, sembelit, kolera dan sakit ulu hati (gastritis) atau sakit maag, hernia, pneumonia, disentri dan penyakit lainnya yang akan dianalisis pada penelitian ini. Ada pun penyakit perut yang butuh penanganan lebih, biasanya didiagnosa oleh tenaga ahli atau pakar, dan pasien harus pergi ke rumah sakit. Diagnosa penyakit perut, sampai saat ini masih dilakukan dengan melakukan konsultasi tatap muka dengan pakar ahli yang mungkin memakan waktu lama serta biaya yang banyak. Kurangnya informasi penderita penyakit perut terhadap gejala penyakit perut, menjadi salah satu menyebabkan pasien tidak mengetahui jenis penyakit perut yang sedang dialaminya.

Hal yang dapat menjadi solusi dari kebutuhan medis ini adalah dengan memanfaatkan kemajuan teknologi. Maka dari itu, dibutuhkanlah sebuah Sistem pakar yang memiliki cara berfikir manusia atau disebut juga dengan Artificial Intellegence atau kecerdasan buatan yang sistem yang akan membantu masyarakat dan para ahli kesehatan dalam menganalisa penyakit perut. Sistem pakar dirancang untuk memberikan jawaban yang masuk akal ketika diberikan satu set kondisi tentang masalah yang dihadapi [1]. Penelitian diagnosa penyakit perut dilakukan dengan menggunakan Metode Certainty Factor. Metode Certainty Factor adalah penalaran bukti yang didasarkan pada pada pengukuran keyakinan hipotesis dan pengukuran yang ditentukan oleh faktor kepastian [2]. Pendekatan Certainty Factor
adalah salah satu kemungkinan metode menguntungkan yang diusulkan untuk menangani masalah kombinasi lapisan data yang berbeda dan ketidakpastian data input [3]. Motode ini memiliki kemungkinan yang menguntungkan karena Certainty Factor dimasukkan ke dalam aturan untuk manajemen ketidakpastian terhadap data masukkan yang digunakan dalam penelitian [4]. Model Certainty Factor (CF) memiliki pertimbangan secara luas dan diselidiki secara eksperimental dalam banyak literatur [5]. Penerapan Sistem Pakar dalam analisis penyakit dan merancang sistem pakar untuk mendiagnosa penyakit penerapan metode Certainty Factor telah dilakukan kaki gajah [11]. Penelitian ini melibatkan pasien dan oleh beberapa peneliti, seperti Sistem Pakar yang pakar dalam mendukung mengoptimalkan hasil. Setiap mengidentifikasi jenis kulit wajah dengan Metode pasien diuji berdasarkan data pakar dan disajikan Certainty Factor. Sistem pakar yang diperlukan kedalam sistem.

membantu memberikan solusi dengan membangun sistem pakar yang dapat mengidentifikasi jenis kulit wajah dengan memasukkan solusi perawatan. Hasil penilaian sistem aplikasi yang telah dibangun oleh responden menyatakan bahwa $88 \%$ dari desain sistem sangat baik dan sangat baik $91 \%$ dari sistem mudah digunakan, dan $98 \%$ mengatakan operasi itu dengan apa yang dibutuhkan [6].
Penerapan Metode Certainty Factor juga dilakukan untuk Sistem Pakar yang mendiagnosis hama dan penyakit pada tanaman tembakau. Dalam penelitian ini, sistem pakar diagnosis hama dan penyakit pada tanaman tembakau dibangun untuk membantu mendiagnosa jenis hama atau penyakit yang menyerang tanaman tembakau, serta memberikan berbagai solusi untuk hama atau penyakit. Persentase pada konsultasi sistem pakar diambil dari hasil tertinggi pertama dan kedua, sebagai alternatif hama lain atau penyakit yang menyerang tanaman tembakau [7].

Sistem Pakar juga diterapkan dalam mendiagnosa depresi mahasiswa akhir dengan metode Certainty Factor berbasis mobile. Untuk itu, dalam penelitian ini kan dilakukan analisa data tingkat depresi pada mahasiswa tingkat akhir menggunakan metode Certainty Factor. Sistem Pakar ini diharapkan dapat memudahkan para pakar dalam penyampaiannya

Kemudian penelitian yang mengimplementasikan Sistem Pakar menggunakan Metode Certainty Factor untuk mendiagnosa dini Corona Virus Desease (COVID-19). Sistem Pakar ini dibangun untuk membantu para tenaga medis dalam mendeteksi dini gejala-gejala yang dialami oleh pasien dan memudahkan pencatatan administrasi oleh pihak rumah sakit, maka salah satunya dibuat Sistem Pakar yang dapat mendeteksi dini COVID-19. Dari 152 data pasien yang diinput pada penelitian ini mendapatkan hasil 114 ODP dengan rata-rata nilai $\mathrm{CF} 91,38 \%, 36$ PDP deangan rata-rata nilai $\mathrm{CF} 98,25 \%$ dan 2 NON dengan rata-rata nilai $\mathrm{CF} 40 \%$. $\mathrm{CF}$ dengan percobaan perhitungan sistem yaitu data yang mewakili pasien mendapatkan nilai CF 0.998848 atau $99.88 \%$ menjadi PDP [9].

Sistem Pakar juga diterapkan dalam mendiagnosis penyakit tumor otak menggunakan Metode Certainty Factor. Sistem Pakar yang dibangun untuk memberikan informasi kepada pengguna mengenai diagnosa penyakit yang diderita berdasarkan gejala - gejala yang diberikan [10]. Lalu penerapan Sistem Pakar yang mendiagnosa penyakit kaki gajah menggunakan Metode Certainty Factor. Penelitian ini mengidentifikasi penyakit kaki gajah dan penyebabnya, serta menerapkan metode Certainty Factor dan entang pentingnya menjaga kondisi badan [8] pakar dalam mendukung mengoptimalkan hasil. Setiap

Jurnal Informasi dan Teknologi Vol . 3 No. 4 (2021) 227-232 


\section{Metodologi Penelitian}

\subsection{Subjek Penelitian}

Subjek dalam penelitian ini berupa implementasi Sistem Pakar dalam menganalisa penyakit perut dengan menggunakan metode Certainty Factor sebagai proses dalam menganalisa gejala dan menentukan nilai kepastian hasil diagnosa. Adapun permasalahan yang menjadi alsan dalam penlitian ini adalah kurangnya informasi yang diperoleh masyarakat tentang penyakit perut sehingga bisa menyebabkan pasien membiarkan
gejala penyakit yang mungkin dapat berdampak lebih buruk bagi kesehatan mereka.

\subsection{Sistem Pakar}

Sistem Pakar merupakan cabang dari kecerdasan buatan yang dikembangkan dan popular pada tahun 1960. Sistem Pakar atau expert system adalah sistem yang menggunakan pengetahuan dengan sistem terkomputerisasi dalam bidang pengetahuan tertentu untuk mencapai sebuah solusi dari masalah pada bidang tersebut [12]. Tujuan utama dari Sistem Pakar bukanlah untuk mengantikan peran seorang pakar (manusia), tetapi sebagai jembatan antara seorang pakar dengan pengguna yang membutuhkan pengetahuan di bidang kepakaran tersebut dan membantu pengguna menyelesaikan masalah mereka.

\subsection{Metode Certainty Factor}

Faktor kepastian (Certainty Factor) diperkenalkan oleh Shortliffe Buchanan dalam pembuatan MYCIN. Certainty Factor (CF) merupakan nilai parameter klinis yang diberikan MYCIN untuk menunjukkan besarnya kepercayaan [13]. Metode ini cocok dipakai dalam Sistem Pakar yang mengandung ketidakpastian.

Bentuk dasar rumus Certainty Factor sebuah aturan JIKA MAKA digunakanlah Persamaan (1).

$$
C F(H, E)=C F=C(\text { E/user }) x C F(\text { rule/pakar })
$$

Untuk menghitung CF (keyakinan) dari kesimpulan diperlukan bukti pengkombinasian dengan rumus pada Persamaan (2).

$$
\left(C F_{1}, C F_{2} / \text { Kombinasi }\right)=C F_{1}+C F_{2}\left(1-C F_{1}\right)
$$

Dari penjelasan kelebihan dan kekurangan Sistem Pakar dapat disimpulkan bahwa metode Certainty Factor yang digunakan tidak membuat sistem sempurna karna metode Certainty Factor ini memiliki kelebihan untuk menunjang Sistem Pakar serta memiliki kekurangan dalam sebuah Sistem Pakar.

\subsection{Metode Pengumpulan Data} Metode pengumpulan data dalam penelitian ini masing - masing penyakit perut tersebut. Lalu data dilakukan dengan wawancara langsung pada pasien yang digunakan untuk pengujian sistem pakar narasumber pakar dalam menentukan gejala dan yang telah dibangun. Di mana data pengujian diperoleh diagnosa penyakit perut di tempat objek penelitian ini dari hasil wawancara dengan petugas kesehatan di dilakukan. Lalu peneliti melakukan studi literatur tempat penelitian dilakukan. dengan mempelajari referensi berupa buku dan penelitian sebelumnya yang relevan dengan penelitian yang dilakukan.

\subsection{Kerangka Kerja}

Kerangka penelitian adalah sebuah konsep penelitian yang menggambarkan hubungan tahapan dari sebuah penelitian, mulai dari mengidentifikasi permasalah hingga pengujian hasil penelitaian. Kerangka penelitian menunjukkan alur kerja penelitian dan menunjukkan pemahaman pokok yang melandasi tahapan penelitian. Kerangka ini diperlukan untuk memperjelas dan mengarahkan penulis agar tidak melenceng dari pokok pembahasan. Terdapat beberapa tahapan dalam melakukan penelitian, berikut ini adalah kerangka kerja penelitian yang menjelaskan tahapan penelitian seperti yang tergambar pada Gambar 1:

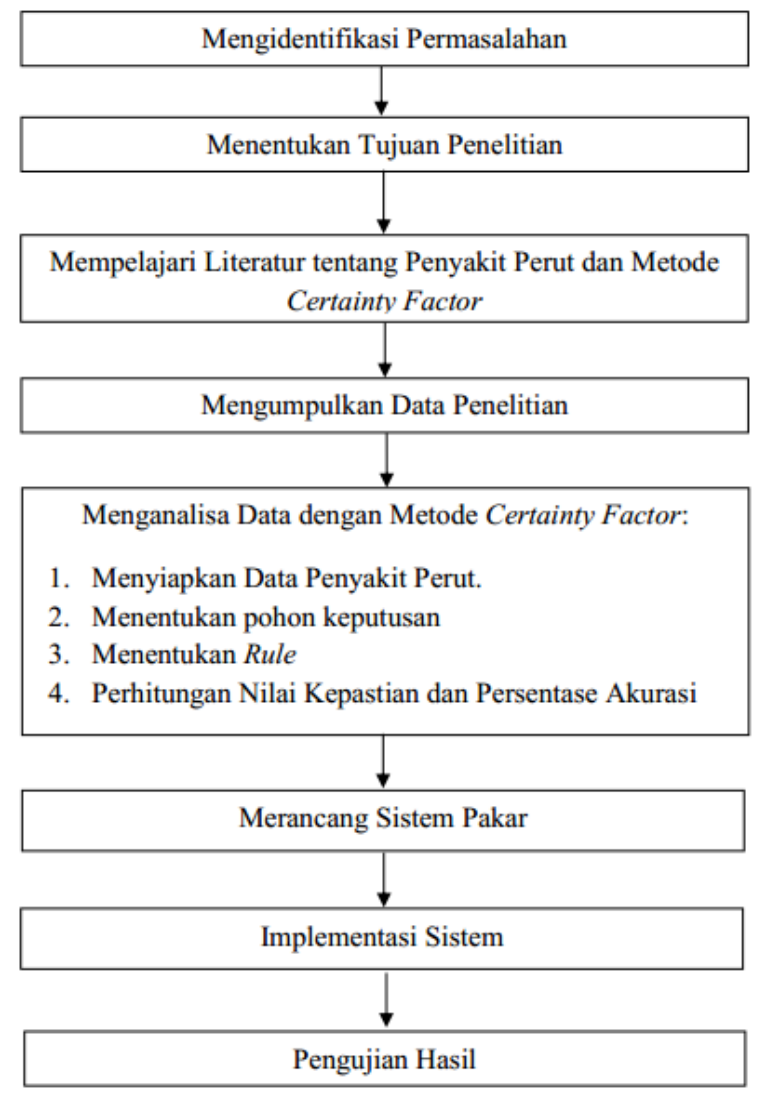

Gambar 1. Kerangka Kerja Penelitian

\section{Hasil dan Pembahasan}

3.1. Analisa Data

Data - data yang digunakan untuk perancangan Sistem Pakar dalam menganalisa penyakit perut adalah data nama penyakit perut, data gejala dari masing - masing penyakit perut, data penyebab dan pencegahan dari 
Dari jenis penyakit yang diperoleh dari hasil persentasi kemungkinan hasil analisis terhadap pengambilan data, kemudian didapatkan gejala dari kemungkina diagnosa. Pilihan gejala pasien dijelaskan semua penyakit. Setiap data penyakit dan gejala diolah pada Tabel 3.

untuk mendapatkan rule. Rule yang didapatkan disajikan pada Tabel 1 .

\begin{tabular}{|c|c|}
\hline Rule & Rule \\
\hline 1. & IF G001 AND G002 AND G003 AND G004 THEN P001 \\
\hline 2. & $\begin{array}{l}\text { IF G005 AND G006 AND G007 AND G008 AND G009 } \\
\text { AND G010 THEN P002 }\end{array}$ \\
\hline 3. & $\begin{array}{l}\text { IF G011 AND G012 AND G013 AND G014 AND G016 } \\
\text { AND G040 THEN P003 }\end{array}$ \\
\hline 4. & $\begin{array}{l}\text { IF G003 AND G008 AND G009 AND G011 AND G014 } \\
\text { AND G016 AND G017 THEN P004 }\end{array}$ \\
\hline 5. & $\begin{array}{l}\text { IF G003 AND G012 AND G018 AND G040 AND G068 } \\
\text { THEN P005 }\end{array}$ \\
\hline 6. & $\begin{array}{l}\text { IF G009 AND G019 AND G020 AND G021 AND G022 } \\
\text { AND G023 THEN P006 }\end{array}$ \\
\hline 7. & $\begin{array}{l}\text { IF G004 AND G008 AND G009 AND G014 AND G023 } \\
\text { AND G024 AND G050 THEN P007 }\end{array}$ \\
\hline 8. & $\begin{array}{l}\text { IF G003 AND G008 AND G012 AND G013 AND G018 } \\
\text { AND G025 AND G026 AND G027 AND G040 THEN P008 }\end{array}$ \\
\hline 9. & IF G030 AND G031 AND G032 THEN P009 \\
\hline 10. & $\begin{array}{l}\text { IF G001 AND G008 AND G025 AND G034 AND G035 } \\
\text { AND G036 THEN P010 }\end{array}$ \\
\hline 11. & IF G011 AND G037 AND G038 AND G039 THEN P011 \\
\hline 12. & $\begin{array}{l}\text { IF G004 AND G012 AND G013 AND G040 AND G041 } \\
\text { AND G042 AND G043 THEN P012 }\end{array}$ \\
\hline 13. & $\begin{array}{l}\text { IF G013 AND G040 AND G041 AND G042 AND G043 } \\
\text { AND G044 AND G045 THEN P013 }\end{array}$ \\
\hline 14. & $\begin{array}{l}\text { IF G003 AND G004 AND G013 AND G015 AND G046 } \\
\text { AND G047 AND G048 THEN P014 }\end{array}$ \\
\hline 15. & $\begin{array}{l}\text { IF G001 AND G008 AND G049 AND G050 AND G051 } \\
\text { THEN P015 }\end{array}$ \\
\hline 16. & $\begin{array}{l}\text { IF G008 AND G009 AND G012 AND G013 AND G015 } \\
\text { AND G052 AND G053 AND G054 THEN P016 }\end{array}$ \\
\hline 17. & $\begin{array}{l}\text { IF G003 AND G008 AND G010 AND G054 AND G055 } \\
\text { AND G062 THEN P017 }\end{array}$ \\
\hline 18. & $\begin{array}{l}\text { IF G008 AND G025 AND G055 AND G056 AND G057 } \\
\text { AND G058 AND G059 THEN P018 }\end{array}$ \\
\hline 19. & $\begin{array}{l}\text { IF G008 AND G009 AND G012 AND G054 AND G060 } \\
\text { THEN P019 }\end{array}$ \\
\hline 20. & $\begin{array}{l}\text { IF G003 AND G008 AND G061 AND G062 AND G063 } \\
\text { THEN P020 }\end{array}$ \\
\hline 21. & IF G042 AND G064 THEN P021 \\
\hline 22. & IF G008 AND G012 AND G018 AND G066 THEN P022 \\
\hline 23. & IF G008 AND G067 AND G068 AND G069 THEN P023 \\
\hline 24. & $\begin{array}{l}\text { IF G008 AND G012 AND G018 AND G040 AND G070 } \\
\text { AND G071 AND G072 AND G073 AND G074 THEN P024 }\end{array}$ \\
\hline
\end{tabular}

Tabel 3. Tabel Gejala Pasien

\begin{tabular}{|c|c|c|c|}
\hline Penyakit & Gejala & Kenyakinan & $\mathrm{CF}(\mathrm{E})$ \\
\hline \multirow{7}{*}{ Gastritis } & Perasaan Kembung Pada & Kemungkinan & 060 \\
\hline & Perut & Besar & 0.00 \\
\hline & $\begin{array}{l}\text { Timbulnya Rasa Mual Dan } \\
\text { Muntah }\end{array}$ & Mungkin & 0,65 \\
\hline & Nafsu Makan Berkurang & $\begin{array}{l}\text { Kemungkinan } \\
\text { Kecil }\end{array}$ & 0,50 \\
\hline & $\begin{array}{l}\text { Sakit Perut Sebelah Kiri } \\
\text { Atas }\end{array}$ & Tidak dipilih & 0,80 \\
\hline & $\begin{array}{l}\text { Serta Perasaan Perut Atas } \\
\text { Penuh Setelah Makan }\end{array}$ & Tidak dipilih & 0,10 \\
\hline & Cepat Kenyang & Tidak dipilih & 0,75 \\
\hline \multirow{6}{*}{ Magg } & Perasaan Kembung Pada & Kemungkinan & 100 \\
\hline & Perut & Besar & 1,00 \\
\hline & $\begin{array}{l}\text { Timbulnya Rasa Mual Dan } \\
\text { Muntah }\end{array}$ & Mungkin & 0,60 \\
\hline & Rasa Nyeri Di Ulu Hati & Pasti & 0,60 \\
\hline & Cepat Kenyang & Tidak dipilih & 0,85 \\
\hline & Bersendawa Ketika Lapar & Tidak dipilih & 0,70 \\
\hline
\end{tabular}

Berdasarkan rule yang telah dibuat, maka hasil perhitungan dari kasus pasien pada Tabel 5 dapat dilakukan dengan menggunakan Persamaan (1) dan (2).

Perhitungan Gastritis:

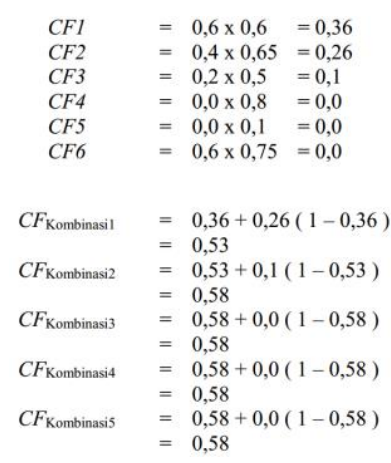

Perhitungan Magg:

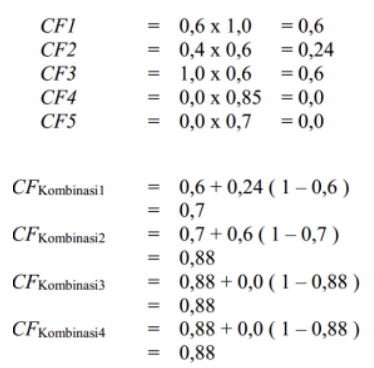

Dari hasil perhitungan CF pada masing - masing gejala yang sudah dilakukan, maka selanjutnya dilakukan penyelesaian dengan Certainty Factor dan diperoleh hasil konsultasi bahwa nilai CF untuk Gastritis adalah 0,58 atau 58\%, sedangkan nilai CF untuk Magg adalah 0,88 atau $88 \%$. Sehingga didapatkan hasil diagnosa pasien adalah penyakit Maag.

Proses perhitungan dimulai dengan memilih gejala yang sesuai dengan basis pengetahuan, lalu mencari 3.2. Validasi

gejala yang terpenuhi oleh gejala terpilih pada basis Penelitian ini dilakukan untuk menganalisa penyakit pengetahuan, dan terakhir melakukan perhitungan perut berdasarkan gejala - gejala yang dialami pasien, 
dan memberikan informasi pada pengguna tentang penyebab dan pencegahan dari tiap - tiap penyakit yang ditampilkan. Pengujian dilakukan dengan menggunakan 30 sample data pasien yang mengalami penyakit perut di wilayah pelayanan objek penelitian. Tingkat akurasi hasil pengujian sistem dapat dicari dengan menggunakan Persamaan (3):

Tingkat Akurasi $=\frac{\text { Jumlah data benar }}{\text { Jumlah data uji }} \times 100 \%$

Hasil akurasi sistem yang diperoleh dari 30 sample data yang diuji dapat dilihat pada Tabel 4.

Tabel 4. Tabel Pengujian Data Pasien

\begin{tabular}{crl}
\hline No & Nama Pasien & Hasil Validasi \\
\hline 1. & PA01 & Tidak Valid \\
2. & PA02 & Valid \\
3. & PA03 & Tidak Valid \\
4. & PA04 & Valid \\
5. & PA05 & Valid \\
6. & PA06 & Valid \\
7. & PA07 & Valid \\
8. & PA08 & Valid \\
9. & PA09 & Valid \\
10. & PA10 & Valid \\
11. & PA11 & Valid \\
12. & PA12 & Valid \\
13. & PA13 & Tidak Valid \\
14. & PA14 & Valid \\
15. & PA15 & Valid \\
16. & PA16 & Valid \\
17. & PA17 & Valid \\
18. & PA18 & Tidak Valid \\
19. & PA19 & Valid \\
20. & PA20 & Tidak Valid \\
21. & PA21 & Valid \\
22. & PA22 & Valid \\
23. & PA23 & Valid \\
24. & PA24 & Valid \\
25. & PA25 & Tidak Valid \\
26. & PA26 & Valid \\
27. & PA27 & Valid \\
28. & PA28 & Valid \\
29. & PA29 & Valid \\
30. & PA30 & Valid \\
\hline
\end{tabular}

Dari Tabel 4, dapat diperoleh hasil akurasi sebagai berikut:

$$
\text { Tingkat Akurasi }=\frac{24}{30} \times 100 \%=80 \%
$$

Dari hasil perhitungan, diperoleh bahwa Sistem Pakar menganalisis penyakit perut dengan menggunakan metode Certainty Factor memiliki akurasi sebesar $80 \%$.

\subsection{Hasil}

Setelah dilakukan pengujian 10 data pasien penyakit perut dengan mengimplementasikan metode Certainty Factor, maka diperoleh hasil pengujian pada Tabel 7 .
Tabel 7. Tabel Pengujian Data Pasien

\begin{tabular}{cclr}
\hline Pasien & Penyakit & Nama Penyakit & Nilai CF \\
\hline PA01 & P020 & Maag & $100 \%$ \\
PA02 & P001 & Sembelit & $78 \%$ \\
PA03 & P024 & Disentri & $100 \%$ \\
PA04 & P023 & Batu Ginjal & $100 \%$ \\
PA05 & P013 & Aneurisma Aorta Perut & $89 \%$ \\
PA06 & P006 & Infeksi Kandung Kemih & $95 \%$ \\
PA07 & P002 & Radang Usus Buntu & $100 \%$ \\
PA08 & P006 & Infeksi Kandung Kemih & $80 \%$ \\
PA09 & P015 & Angina & $98 \%$ \\
PA10 & P020 & Maag & $94 \%$ \\
\hline
\end{tabular}

Hasil implementasi dari Sistem Pakar Penyakit Perut dapat diakses melalui perangkat lunak browser dalam versi web. Adapun tampilan halaman utama dari sistem dapat dilihat pada Gambar 2.

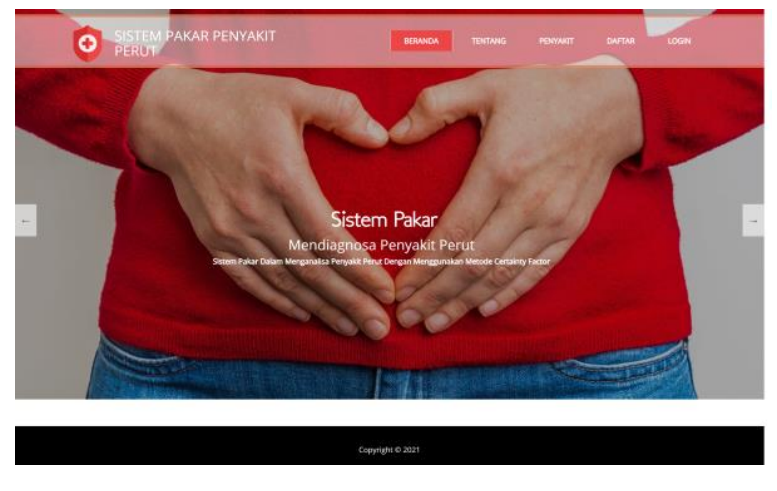

Gambar 2. Halaman Utama

Untuk menggunakan fungsi konsultasi, pengguna dapat melakukan registrasi terlebih dahulu untuk mendapatkan akun sehingga bisa login ke dalam sistem. Halaman konsultasi sistem dapat dilihat pada Gambar 3.
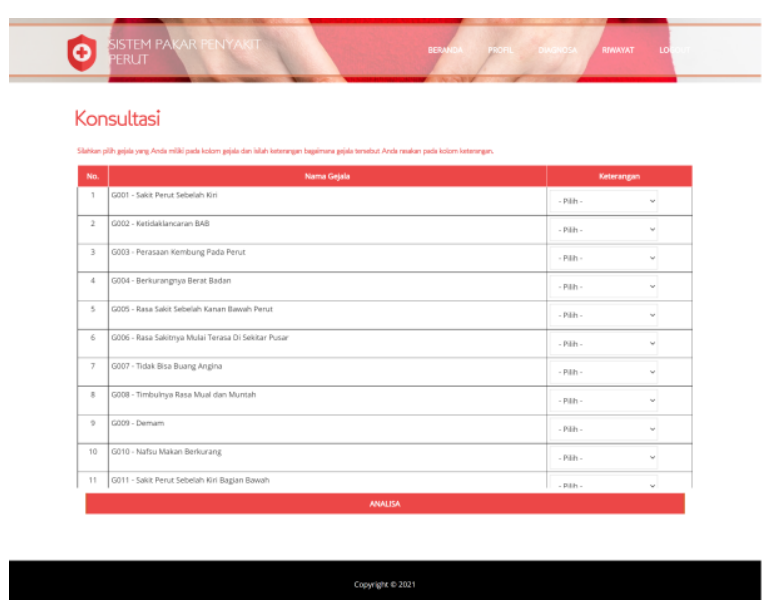

Gambar 3. Halaman Konsultasi

Di halaman konsultasi, pengguna dapat memilih gejala - gejala penyakit perut yang dimiliki oleh pasien. Masing masing gejala memiliki keterangan (parameter) bagaimana pasien merasakan gejala tersebut. Dan jika pengguna telah elesai memilih gejala, maka pengguna dapat menekan tombol Analisa untuk memproses gejala pasien. Hasil analisa kemudian ditampilkan oleh sistem seperti pada Gambar 4. 


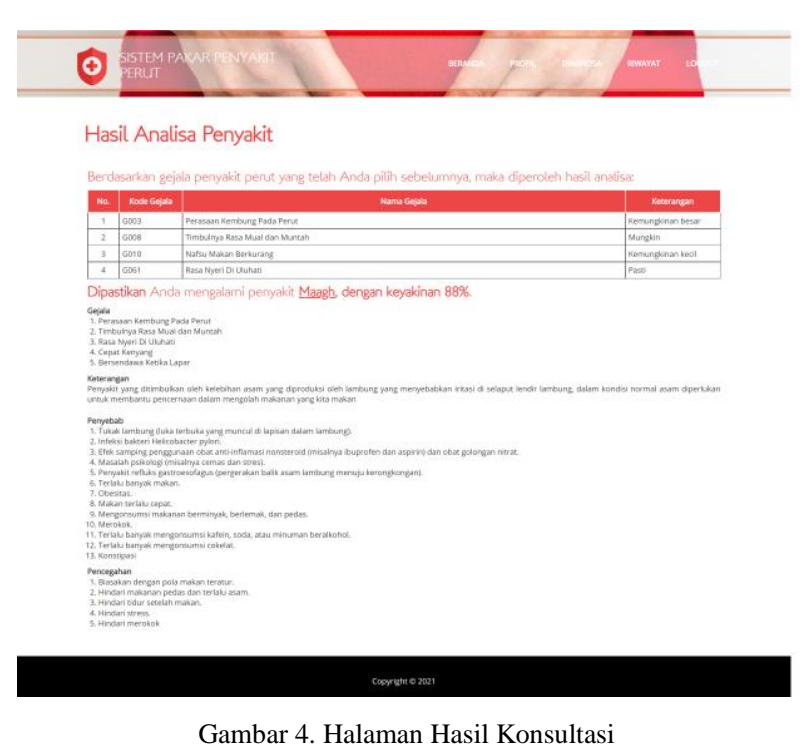

Pada halaman hasil konsultasi, sistem akan menampilkan hasil analisa berupa diagnosa penyakit perut yang dialami oleh pasien berdasarkan gejala yang telah dipilih sebelumnya. Sistem juga menampilkan parameter kepastian hasil dan persentasi kepastian hasil analisa. Dan untuk menambah informasi bagi pengguna, sistem akan menampilkan keterangan gejala, penyebab, dan pencegahan dari penyakit hasil analisa pasien. Pada hasil yang tampil di Gambar 4 terlihat bahwa pasien yang melakukan konsultasi mengalami penyakit Maag dengan parameter "Dipastikan" dan persentase keyakinan sebesar $80 \%$.

\section{Kesimpulan}

Sistem pakar dalam menganalisis penyakit perut berhasil diimplementasikan, dan setelah dilakukan pengujian terhadap 74 gejala dan 24 jenis penyakit perut yang terjadi diperoleh bahwa pengujian akurasi sistem terhadap 30 data sebagai dataset pengujian untuk diperoleh hasil tingkat akurasi sebesar $80 \%$. Kemudian hasil analisa dari permasalahan penelitian bahwa dari data yang diperoleh dapat disimpulkan masyarakat wilayah pelayanan Puskesmas Salido memiliki keinginan yang kurang untuk dating mengkonsultasikan gejala penyakit perut mereka pada layanan kesehatan. Hal ini terlihat dari kumpulan data pasien yang diperoleh hanya sedikit pasien yang dating dengan keluhan penyakit perut. Maka dari itu, diharapkan Sistem Pakar ini mampu membantu masyarakat untuk berkonsultasi tanpa harus mengunjungi tempat pelayanan kesehatan.

\section{Daftar Rujukan}

[1] Rupnawar, A., Jagdale, A., \& Navsupe, S. (2016). Study on Forward Chaining and Reverse Chaining in Expert System.
International Journal of Advanced Engineering Research and Science, 3(12), 60-62. https://doi.org/10.22161/ijaers/3.12.12

[2] Eu, Kok Seng \& Yap, Kian Meng. (2020). Overcoming Long Recovery Time of Metal-Oxide Gas Sensor With Certainty Factor Sensing Algorithm. International Journal on Smart Sensing and Intelligent Systems. 7. 1-6. https://doi.org/10.21307/ijssis-2019-077

[3] Devkota, K.C., Regmi, A.D., Pourghasemi, H.R. et al. (2013) Landslide susceptibility mapping using certainty factor, index of entropy and logistic regression models in GIS and their comparison at Mugling-Narayanghat road section in Nepal Himalaya. Nat Hazards 65, 135-165. https://doi.org/10.1007/s11069-012-0347-6

[4] Konstantinopoulou, G., Kovas, K., Hatzilygeroudis, I. \& Prentzas, J. (2019). An Approach using Certainty Factor Rules for Aphasia Diagnosis. 10th International Conference on Information, Intelligence, Systems and Applications (IISA), 1-7, doi: https://doi.org/10.1109/IISA.2019.8900782

[5] Pourghasemi, H.R., Pradhan, B., Gokceoglu, C. et al. (2013). Application of weights-of-evidence and certainty factor models and their comparison in landslide susceptibility mapping at Haraz watershed, Iran. Arab J Geosci 6, 2351-2365. https://doi.org/10.1007/s12517-012-0532-7

[6] Santi, I.H. and Andari, B. 2019. Sistem Pakar Untuk Mengidentifikasi Jenis Kulit Wajah dengan Metode Certainty Factor. INTENSIF: Jurnal Ilmiah Penelitian dan Penerapan Teknologi Sistem Informasi. 3, 2 (Jul. 2019), 159-177. https://doi.org/10.29407/intensif.v3i2.12792

[7] Arifin, Mohammad \&, Slamin \& Retnani, Windi. (2017). Penerapan Metode Certainty Factor Untuk Sistem Pakar Diagnosis Hama Dan Penyakit Pada Tanaman Tembakau. $\begin{array}{llll}\text { BERKALA SAINSTEK. } & 5 .\end{array}$ https://doi.org/10.19184/bst.v5i1.5370.

[8] Supiandi, Apip \& Chandradimuka, Damar. (2018). Sistem Pakar Diagnosa Depresi Mahasiswa Akhir Dengan Metode Certainty Factor Berbasis Mobile. Jurnal Informatika. 5. 102-111. https://doi.org/10.31311/ji.v5i1.2872.

[9] Suryana, Muhamad \& Kasyfi, Fauziah \& Titi, Ratih. (2020). Implementasi Sistem Pakar Menggunakan Metode Certainty Factor Untuk Mendiagnosa Dini Corona Virus Desease (COVID19). JURNAL MEDIA INFORMATIKA BUDIDARMA. 4. 559. https://doi.org/10.30865/mib.v4i3.2132.

[10]Nst, Yeni \& Aan, Mesran \& Gienam, Suginam \& Fadlina, Fadlina. (2017). Sistem Pakar Untuk Mendiagnosis Penyakit Tumor Otak Menggunakan Metode Certainty Factor (CF). Jurnal INFOTEK. 2. 82-86.

[11]Hasibuan, N.A. \& Sunandar, Hery. \& Alas, S. \& Suginam. (2017). Sistem Pakar Mendiagnosa Penyakit Kaki Gajah Menggunakan Metode Certainty Factor. JURASIK. 2. http://dx.doi.org/10.30645/jurasik.v2i1.16.g13

[12] Army, Widyalelisa. (2018). Sistem Pakar Diagnosis Penyakit Menular Dengan Metode Forward Chaining Dan Certainty Factor. Jurnal Sains dan Informatika. 4. 171. https://doi.org/10.22216/jsi.v4i2.3684.

[13] Octavina,Yossi. \& Fadlil, Abdul. (2014). Sistem Pakar Untuk Mendiagnosa Penyakit Saluran Pernapasan dan Paru Menggunakan Metode Certainty Factor. Jurnal Sarjana Teknik Informatika. 2(2). http://dx.doi.org/10.12928/jstie.v2i2.2642 